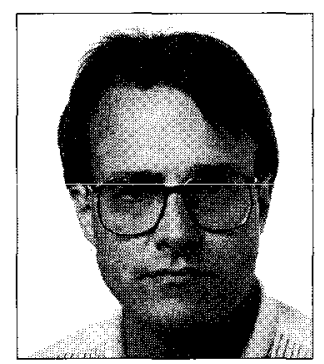

Juha Sihvonen

\title{
SIVISTYSTÄ KAIKILLE VAI VALITUILLE?
}

Syyskuun 6. päivänä julkaistussa kannanotossaan opetusministeri Olli-Pekka Heinonen totesi näin: "Kansalaisopistot ovat säilyttäneet läpi vuosien asemansa yhtenä maamme suurimmista aikuiskoulutusmuodoista. Yhtenä syynä ovat tavattoman monipuolinen opiskelutarjonta, jossa on osattu kullakin paikkakunnalla ottaa huomioon sikäläisen väestön erityistarpeet." Eräs kansalaisopiston valtti onkin Heinosen mielestä siinä, että se on läsnä kaikkialla. Kynnys lähteä opiskelemaan on alhainen ja myös kurssimaksut ovat pysyneet kohtuullisina.

Lopuksi Heinonen korosti kannanotossaan, että kansalaisopistot ovat yleissivistävinä oppilaitoksina tarjonneet runsaasti mahdollisuuksia kansalaisvalmiuksien lisäämiseen, monipuoliseen harrastamiseen ja itsensä kehittämiseen. "Nämä tehtävät ovat edelleen ajankohtaisia ja yhteiskunnan niille osoittaman tuen arvoisia."

Ministerin lausunnon perusteella voisi luulla, että kansalaisopistoissa on kaikki hyvin. Mutta onko opetusministerin tilannearvio oikea?

Annan seuraavaksi puheenvuoron yhdelle tutkimukseeni osallistuneelle rehtorille. Hän työskentelee pienessä maaseudun kansalaisopistossa. Sain häneltä syksyllä kirjeen, josta piirtyi aivan toisenlainen kuva kuin ministerin puheessa. Hänen luvallaan siteeraan kirjettä:

"Vielä yritän pitää tätä opistoa, vaikka se silmissä kuihtuu. Täällä on seitsemän ja puolituhatta asukasta. Juuri kukaan ei valita ohjelman vähäisyyttä, joku joskus soittaa ja toivoo paritanssia tai kompostointia. Kun katselen muiden opistojen ohjelmia totean, että määrässä löytyy, mutta monia muita nimikkeitä ei ole. Tietenkään kaikki meidän hyvät tarkoituksemme eivät toteudu. Ihmettelenkin, onko minulla oikeutta ajaa tätä opistoa alas.”

Herää kysymys, kumman - ministerin vai rehtorin - tilannearvio on oikea? Eikö ministeri kenties tunne opistojen todellista tilannetta vai onko kyseisen rehtorin opisto poikkeustapaus? Vai puhuvatko molemmat totta? Ovatko opistotoiminnan ääripäät näin kaukana toisistaan? Mm. näihin kysymyksiin pyrin vastaamaan väitöskirjassani "Sivistystä kaikille vai valituille? Kansalaisopistotoiminnan kehitys vapaasta kansanvalistustyöstä maksupalveluun".

Lähes 100-vuotias opistotoiminta käy parhaillaan läpi historiansa voimakkainta murroskautta. Tähän verrattavia mullistuksia opistot ovat kokeneet aikaisemmin vain 1920 - ja 1960-luvuilla. Opistotoiminnan nykyinen murros koskee kaikkia toiminnan osa-alueita, kuten opistotoiminnan arvoperustaa, tehtäväkäsitystä, -alaa, hallintoa ja taloutta. Myöskään rehtoreiden tehtävät eivät ole säilyneet ennallaan. Murroksen seurauksena opistotoiminnan luonne on muuttumassa kokonaan toiseksi kuin mihin tähän mennessä olemme tottuneet.

Opistojen tulee ratkaista, miten ne sopeutuvat kiristyneeseen kilpailuun aikuiskoulutusmarkkinoilla, uuden lainsäädännön suomiin lähes täydellisiin toimintavapauksiin, julkisen tuen ehtymiseen, kunnalishalinnon muutok- 
siin, tulosjohtamiseen jne. Sanalla sanoen opistojen tulee sopeutua 1970- ja 80-lukujen suunnittelukeskeisen aikuiskoulutuspolitiikan sijasta 1990-luvun markkinaperusteiseen aikuiskoulutuspolitiikkaan.

Eikä tässä kyllin. Monet opistotoimintaa koskevat uudistukset ovat saaneet 1990 luvun alun laman seurauksena aivan toisen luonteen, kuin mihin niillä oli tarkoitus pyrkiä. Usean vuoden ajan yleinen mielenkiinto on kohdistunut pitkäjänteisen kehittämistyön sijasta nopeitten taloudellisten säästöjen aikaansaamiseen ja toiminnan tuloksellisuuden parantamiseen. Leikkaukset seurasivat toinen toistaan niin lyhyellä varoitusajalla, että ainoaksi keinoksi usein jäi hätäinen toiminnan supistaminen.

Millainen sitten on opistotoiminnan 1990-luvun alun murroskauden tilinpäätös? Ensinnäkin kansalaisopistojen asema aikuiskoulutusjärjestelmässä on muuttunut. Näyttää siltä, että opistor ovat ministerin vakuutteluista huolimatta epäonnistuneet perustelemaan päättäjille toimintansa tarpeellisuutta. Tästä kertoo opistojen saaman julkisen tuen selvä väheneminen suhteessa muihin aikuiskoulutusorganisaatioihin. Valtion ja kuntien säästötoimien myötä opistojen valtionapuun oikeuttavia oppitunteja leikattiin vuosina 1990-95 yhteensä runsaat 17 prosenttia. Kansanopistot ja opintokeskukset onnistuivat säilyttämään opetusvolyyminsa jokseenkin ennallaan, mutta lamasta huolimatta tai oikeammin juuri lamasta johtuvan massatyöttömyyden vuoksi - ammatillinen aikuiskoulutus kasvatti osuuttaan useilla kymmenillä prosenteilla. Juhlapuheissa opistotyön merkitys kyllä tunnustetaan, mutta resurssienjaossa näillä puheilla ei tunnu olevan merkitystä.

Mitkään yhteiskunnalliset kehityspiirteet eivät kuitenkaan tue sellaista johtopäätöstä, että yleissivistävän aikuiskoulutuksen merkitys olisi vähenemässä. Päinvastoin, kaikkinainen epävarmuuden lisääntyminen yhteiskunnassa ja työmarkkinoilla, tiedontulvan kasvu, muutostahdin nopeutuminen, kansainvälistyminen jne. korostavat entisestään laajan yleissivistyksen merkitystä.

Tällaiseen arvioon päädytään esimerkiksi juuri valmistuneessa Helsingin yliopiston kokoamassa Eurodelfoi-tutkimuksen maakohtaisessa raportissa, joka perustuu yli sadan aikuiskoulutuksen asiantuntijan tekemiin arviointeihin Suomen aikuiskoulutusjärjestelmän tilasta ja tulevaisuudesta. Opistojen toimintaedellytysten heikentämistä voidaankin pitää lyhytnäköisenä koulutuspolitiikkana.

Toiseksi opistokentän sisällä on tapahtumassa voimakas eriytyminen. Ne opistot tuntuvat menestyvän aikuiskoulutusmarkkinoiden kiristyvässä kilpailussa, jotka sijaitsevat riittävän suurissa asutuskeskuksissa ja jotka ovat uskaltaneet uudistaa toimintatapojaan. Tilanne on sen sijaan käymässä tukalaksi maaseudun pienissä opistoissa, kuten alussa lainaamani rehtorin puheenvuorokin osoittaa. Näiden opistojen asema riippuu ratkaisevasti siitä, millaista koulutuspolitiikkaa maassamme harjoitetaan. Maaseudun pienten opistojen omat keinot tilanteensa helpottamiseksi ovat varsin rajalliset.

\section{Voidaankin kysyä, onko Suomella varaa päästää rapistumaan se ainutlaatuinen, koko maan kattava opistoverkosto, joka tänne on kovalla työllä vuosikymmenien kuiuessa onnistuttu íuomaan. Verkoston säilyttäminen tulee varmasti halvemmaksi kuin sen rakentaminen joskus myöhemmin uudelleen, jos ja kun vapaan sivis- tystyön yhteiskunnallinen merki- tys jälleen oivalletaan.}

Kolmanneksi 1990-luvun alun lamakausi ja sinä aikana muotiin tullut markkinaperusteinen aikuiskoulutuspolitiikka ovat jälleen tehneet ajankohtaiseksi kysymyksen sivistyksellisestä tasa-arvosta. Kysyntäpainotteinen toimintamalii on johtanut selvään ristiriitaan sivistyksellisen tasa-arvon edistämisen kanssa. Tutkimukseeni osallistuneiden rehtoreiden vastauksista kävi ilmi, että tasa-arvon puolustamista pidetään edelleen kaikkein tärkeimpänä opistotoiminnan perusarvona. Kokemukset kansalaisopistoista osoittavat, että kohonneet kurssimaksut muodostavat tietyllä tasolla selvän esteen koulutuk- 
seen hakeutumiselle. Juuri kysymys sivistyksellisen tasa-arvon tavoitteesta aikuiskoulutuspolitiikassa nousikin tärkeimmäksi koulutuspoliittiseksi teemaksi tutkimuksessani.

Edellä mainittujen kehityspiirteiden vuoksi kansalaisopistot kykenevät yhä huonommin tarjoamaan sivistystä kaikille. Kansalaiset ovat jakautumassa myös sivistyksellisesti entistä selvemmin A- ja B-luokkaan, eivätkä opistotkaan kykene enää tarjoamaan sellaista "toista vaihtoehtoa" kuin aikaisemmin. Pidän tämän kehityssuunnan esilletuloa koulutuspoliittisesti kaikkein huolestuttavimpana havaintona tutkimuksessani.

Edellä esitettyä opistotoiminnan kehitystä voidaan selittää markkinaperusteisen aikuiskoulutuspolitiikan konseption avulla. Hallitsevana pyrkimyksenä siinä on koulutuspalvelujen nopea sopeuttaminen työmarkkinoiden muuttuviin tarpeisiin. Suunnittelun tilalle on tullut oppilaitosten välinen kilpailu koulutustehtävistä ja maksukykyisistä asiakkaista.

Nykyisten aikuiskoulutusmarkkinoiden vaatima kysyntäpainotteinen toimintamalli valtaa alaa kaikissa niissä opistoissa, joissa toimintaympäristö antaa siihen mahdollisuuden. Muut eli lähinnä pienet opistot joutuvat sopeuttamaan toimintansa julkisen tuen asettamiin raameihin.

Tutkimukseni tulokset vastaavat hyvin Peter Jarvisin tekemiä kansainvälisiä havaintoja aikuiskoulutusmarkkinoiden kehityksestä. Jarvis kiteyttää havaintonsa seuraavasti: "Koulutus on aina ollut varattu niille, joilla on ollut siihen varaa. Tämän vuosisadan puolenvälin tienoilla se oli vihdoin onnistuttu avaamaan kaikille haluaville, niin että etuoikeutettujen hankkima kulttuuripääoma tuli myös kaikkien muiden sitä haluavien ulottuville. Nyt ovat koulutuslaitokset vaihtaneet rooliaan palvelun tuottajista hyödykkeen myyjiksi. Ne joutuvat taas suosimaan yhteiskunnan etuoikeutetumpia kerrostumia, joilla on varaa niiden tarjoamiin hyödykkeisiin."

Meillä Suomessa voidaan pohtia, johtaisiko opistotoiminnan ja mahdollisesti koko vapaan sivistystyön julkisen tuen lakkauttaminen sivistystyön loppumiseen maastamme. Olen varma, ettei näin kävisi. Niin kauan kuin ihmistä ei ole alistettu pelkäksi työvoimaksi, niin kauan vapaalla sivistystyöllä on kysyntää. Sivistystyötä siis tehtäisiin edelleen jossakin muodossa, mutta siitä tulisi harvojen ja valittujen etuoikeus. Jos kansalaisopistoilta viedään mahdollisuus tarjota väylä kansalaisten sivistysharrastuksille, jokin muu taho tekee sen niiden puolesta. Eikä ole mitenkään vaikeaa arvata, millaiset koulutuksen järjestäjät täyttäisivät opistojen jättämän tyhjiön nykyisinä aikuiskoulutusmarkkinoiden luvattuina aikoina. Näitä koulutuksen järjestäjiä tuskin kiinnostaisi vapaan sivistystyön tasaarvoulottuvuus, vaan mahdol-lisuus maksukykyisten asiakkaiden rahastamiseen kulloinkin huudossa olevilla muotikursseilla.

Miten voitaisiin ratkaista ristiriita sivistyksellisen tasa-arvopyrkimyksen ja koulutusmarkkinoiden vaatiman kysyntäpainotteisen toimintamallin välillä? Ruotsalaisen tutkijan Kjell Rubensonin mukaan yleistä aikuiskasvatusta tarjoavan koulutusorganisaation, joka haluaa pyrkiä opintojen tasa-arvoistamiseen, on markkinavoimien vaatimuksesta omaksuttava ainakin osittain kysyntään perustuva kehittämismalli.

Jos organisaatio tähtää toiminnassaan ainoastaan tasa-arvoisuuden edistämiseen, se menettää pian oikeutuksen toiminnalleen. Tämä merkitsee Rubensonin mielestä sitä, että jatkossa organisaation on mahdotonta tarjota edes niitä muutamia tasa-arvoisuuteen pyrkiviä palveluja, joita se on aikaisemmin tuottanut. Muutoksen aikaansaamisen kannalta onkin Rubensonin mukaan välttämätöntä, että aikuiskasvatuksen tuki osoitetaan tulevaisuudessa erityisesti tasa-arvopäämääriin tähtäävään toimintaan suuremmassa määrin kuin tähän asti. Voin yhtyä Rubensonin arvioon: se pätee myös kansalaisopistoihin. Opistotoiminnassa on syytä löytää tasapaino kysyntäpainotteisen ja julkiseen rahoitukseen perustuvan toimintamallin välille.

Lectio praecursorian (lyhennelmä) 18.12.1996 Tampereen yliopistossa pidetyssä väitöstilaisuudessa, missä Juha Sihvonen puolusti tutkimustaan Sivistystä kaikille vai valituille? Kirja-arvio tutkimuksesta ilmestyy numerossa 2/97. 